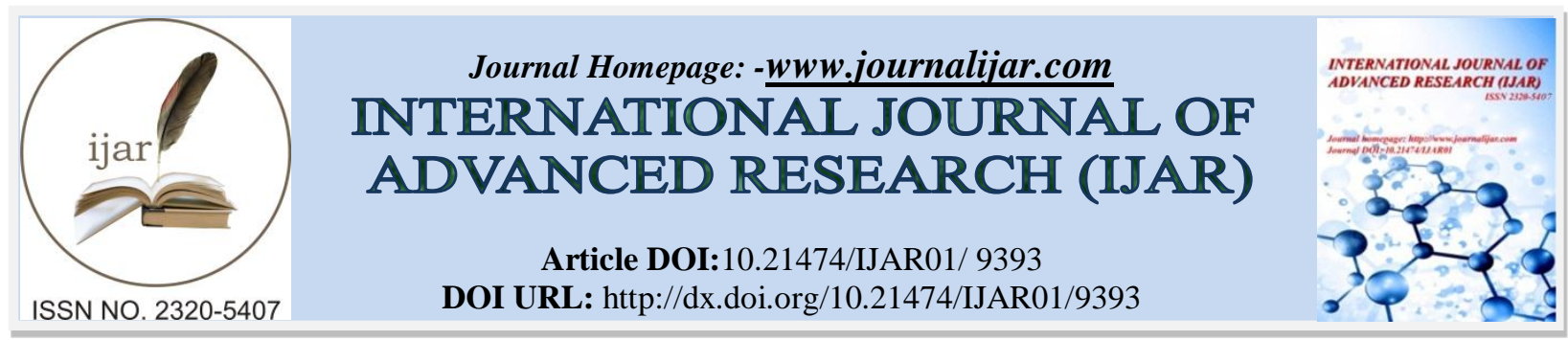

RESEARCH ARTICLE

\title{
EFFECT OF VASANTIKA VAMANA ON VARIOUS KAPHAJA VIKARAS ( KITIBHA KUSHTA, STHOULYA, TAMAKA SWASA AND HYPOTHYROIDISM).
}

Dr. Kirankumari.Rathod ${ }^{1}$ and Dr. Anant $S$ Desai ${ }^{2}$.

1. PG Scholar, Dept of Panchakarama, Govt.Ayurvedic Medical College Bangalore.

2. HOD Dept of Panchakarama, Govt.Ayurvedic Medical College Bangalore.

\section{Manuscript Info}

Manuscript History

Received: 15 May 2019

Final Accepted: 17 June 2019

Published: July 2019

\section{Key words:-}

Vasantika vamana, Kitibha kushta, Sthoulya, Tamaka swasa, and Madana phala pippali.

\begin{abstract}
Ayurveda believes the state of seasonal changes influence the biological system resulting into the accumulation and aggravation of particular dosha in a particular season like accumulation of kapha dosha in Shishira rutu and aggravation of it in Vasanta rutu. Vasantika vamana is conducted in spring season approximately in the month of March and April for the elimination of vitiated kapha dosha.

Kitibha kushta, Sthoulya, Tamaka swasa and Hypothyroidism is a kapha pradhana bahudoshaavstha janya vyadhis. There was aggravation of symptoms are seen in Shishira rutu by adopting the Shishira rutucharya i.e indulging of madhura,amla, lavana rasa, snigdha and sheeta guna ahara as these are the disease provocating nidanas. Hence Vamana karma is done in Vasanta rutu to expel the vitiated Kapha dosha.

For Deepana and Pachana- Chitrakadivati was selected. Snehapaana with Murchita grita is administered till Samyak snigdha lakshanas. Abhyanga with Murchita tila taila followed by Ushnajala snana as swedana karma was advices in Vishrama kaala. Kapha utkleshakara ahara are advised in Vishrama kaala for utkleshana of kapha dosha. Madana phala pippali chorna added with Yashimadhu choorna, Vacha choora, Saindhava lavana and Madhu was administered as vamaka yoga.

Assessment of symptoms of these diseases is done before starting of Deepana and Pachana and after Vamana karma is analysed statistically by using student "t" test.

After Vamana karma statistically highly significant results are observed in the symptoms of these diseases.
\end{abstract}

Copy Right, IJAR, 2019,. All rights reserved.

\section{Introduction:-}

Vamana karma is one among 5 Pradhanakarma ${ }^{(1)}$ and prime treatment modality told for Kaphaja disorders ${ }^{(2)}$. As it is preventive, promotive and curative treatment for kaphaja disorder. Vasantika vamana conducted in spring season approximately in the month of March and April for the elimination of vitiated kapha dosha which help to prevent the forth coming kapha disorder and associated pitta disorder or diseases originating or settled in the place of kapha dosha.

Corresponding Author:-Dr Kirankumari.Rathod. 
Different seasonal changes occurring in the environment greatly influence the biological system resulting into accumulation and aggravation i.e Sanchaya and Prakopa of particular dosha in respective season. The Vruddhi or aggravation of Kapha dosha takes place in Shishira rutu due to not following the Rutucharya properly ${ }^{(3)}$, which lead to the Prakopa or vitiation of kapha dosha in Vasanta rutu ${ }^{(4)}$. The vamana karma adopted in this rutu help in normalisng this dosha thereby help in maintaining the health.

In Shishira rutu, madhura, amla, lavana rasa, food prepared from ikshu rasa, and guda, snigdha guna ahara are advised because of Prabalata of agni $^{(5)}$. These are the nidanas for Kitibha kushta ${ }^{(6)}$, Sthoulya ${ }^{(7)}$, Tamaka swasa ${ }^{(8)}$ and Hypothyroidism. These nidanas further increases the symptoms of these diseases.

Kitibha kushta, Sthouly, Tamaka swasa and Hypothyroidism are the bahudosha avashta vyadhi. All this disease have the kapha dosha predominant hence Vamana karma is adopted in these disorder in Vasanta rutu to eliminated the vitiated kapha dosha.

\section{Aim and objectives:-}

1. To assess the role of Vasanta rutu in induction of Vamana karma

2. To evaluate the effect of Vasantika vamana in Kitibha kushta

3. To evaluate the effect of Vasantika vamana in Sthoulya

4. To evaluate the effect of Vasantika vamana in Tamaka swasa

5. To evaluate the effect of Vasantika vamana in Hypothairodism

\section{Materials and methods:-}

The patients who are indicated for Vamana karma were selected from the OPD and IPD of SJIIM hospital Bengaluru. 56 subjects are registered, out of which 16 subjects are discontinued the treatment and 40 subjects are completed the whole treatment.

Chart No 01:-Conort Flow Diagram

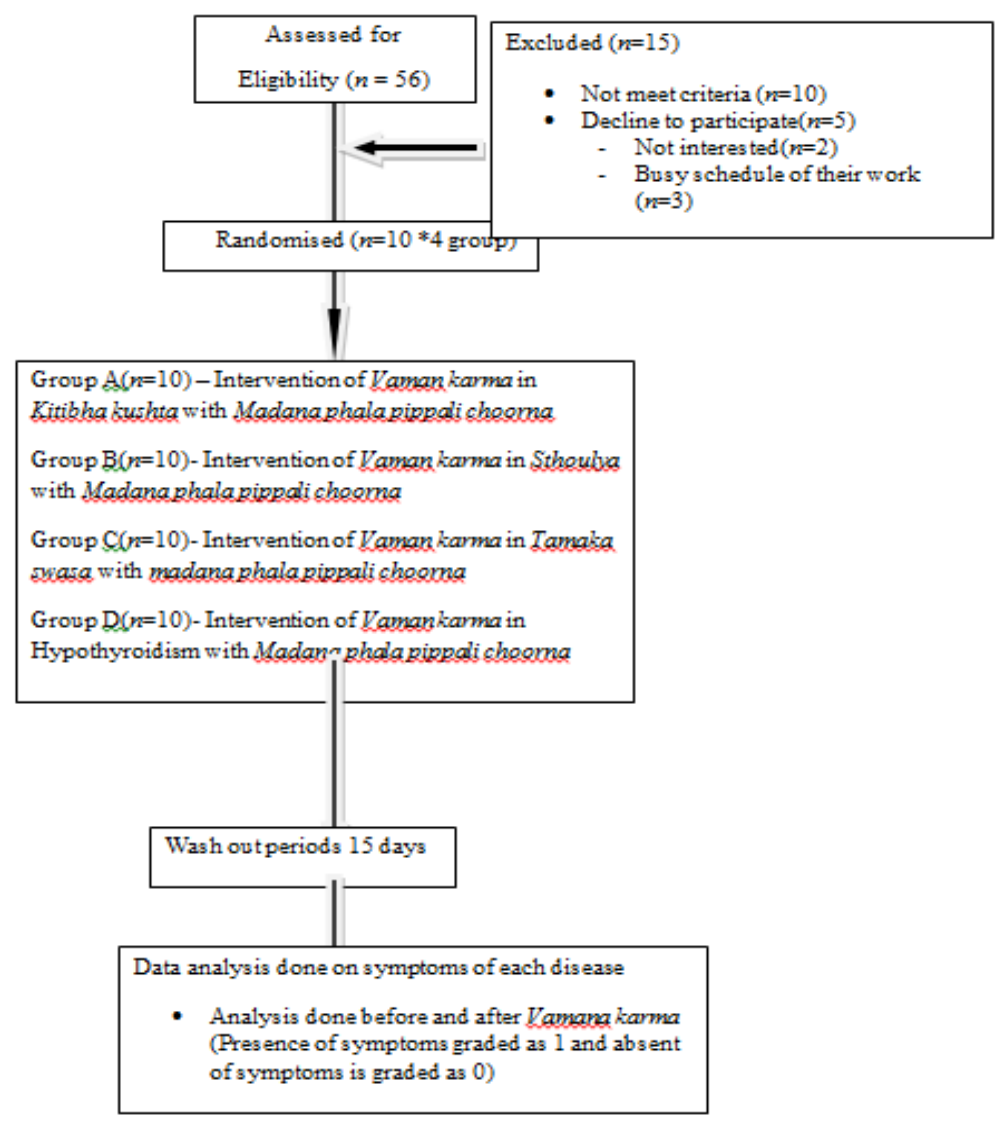




\section{Inclusion criteria}

1. Age between $16-60 y r s$ are selected

2. Patients fit for Vamana karma are selected

3. Patients having symptoms of Kitibha kushta, Sthoulya, Tamaka swasa and Hypothyroidism are selected for the study.

\section{Exclusion criteria}

Patients suffering from systemic disorder like tuberculosis, ischemic heart disease and other life threatening disease which interfere the Vamana karma procedure.

\section{Assessment criteria}

The symptoms of Kitibha kushta, Sthoulya, Tamaka swasa and Hypothairoidism assessed before starting of Deepana and Pachana after completion of Vamana karma is assessed.

Method of intervention: is divided in three stage as

\section{Purva karma}

1. For Deepana and Pachana- Chitrakadi vati ${ }^{(9)}, 1$ tid was administered, till nirama avastha was observed.

2. For Sneha pana - Murchita grita is selected. Administered in arohaha karma. Initial dose started with $30 \mathrm{ml}$ in morning around 6:00 AM. Ushnajala as anupana is advised. Sneha paana was given till Samyak snigdha lakshanas are observed. Only Koshta snigdhata was observed in Kitibha kushta and Sthouly as these are the kleda pradhana vyadhi.

3. For Sarvanga abhyanag- Murchita tila taila was selected. 3 sitting of Sarvanga abhyanag was advised i.e on the day of Vishrama kaala morning and evening time and on the day of Vamana karma in morning time.

4. For Swedana karma- Ushnaja snana was advised after Sarvanga abhyanag. 3 sitting of Ushnajala snana is advised followed by Sarvanga abhyanga.

5. Utkleshakara ahara- during Vishrama kaala, Utkleshakara ahara are advised. Utkleshakara ahara like doodh peda, curd rice, milk payasa, curd sugar are advised to the patients.

\section{Pradhana karma}

1. Akanta paana- for Akanta paana, Ksheera is used. Around 1.5 Litters of Kheera is administered for each patient.

2. Administration of Vamanka dravya- Madana phala pippali processed in Grita, Dadhi and Madhu ${ }^{(12)}$ are administered for each patient.

1. Madana phala pippli choorna $-3 \mathrm{gms}$

2. Yashtimadhu choorna - 2gms

3. Vacha choorna $-1 \mathrm{gm}$

4. Saindhava lavana- $1 / 2 \mathrm{gm}$

5. Madhu - Q.S

Vamanopaga dravya- Yashtimadhu Kashaya and Saindhava jala is administered for each patients as Vamanopaga. Administered till the Antaki lakshanas are observed like Pittanta/ Kapha chedana.

\section{Paschat karma ${ }^{(10)}$}

1. Sheeta jala sinchana - sprinkling of cold water to the pani, pada and mukha pradesha.

2. Doomapaana - Haridravarti is given for each patient after Sheeta jala sinchana.

3. Samsarjana krama - Peyadi samsarjana krama is advised for 3Annakala based on the Vaigiki shudhi for 3, 4 and 5 days respectively.

\section{Observation on Vasantika Vamana karma}

Assessment of Vamana karma : It was assessed as Pravara, Madyama and Hina shuddhi on the basis of four criteria $^{(11)}$ :

1. Vaigiki criteria: Maximum number of patients are showed Svayam pravrutti of Vegas i.e $76.66 \%$. The forceful expulsion of Vegas is observed during the study. The maximum number of patients had Pravara Shuddhi i.e $70 \%$ (6 to 7 Vegas )

2. Manaki criteria: The maximum number of patient's i.e $66.66 \%$ shows around $172.15 \mathrm{ml}$ of output extra as compare to the input. 
3. Antaki criteria: In 27 patients i.e $66.66 \%$ patients showed Pittanta and 13 patients showed Kapha chedana i.e around $46.66 \%$.

4. Laingiki criteria ${ }^{(12)}$ :

Table no 1:-Showing percentage of improvement in Laingiki parameter

\begin{tabular}{|r|r|}
\hline Laingiki lakshanas & Percentage of patients \\
\hline Indriyaprasada (freshness of sense organ) & $75 \% \%$ \\
\hline Laghuta (lightness) & $80 \%$ \\
\hline Vatanulomana & $100 \%$ \\
\hline
\end{tabular}

\section{Results:-}

Effect of Vasantika vamana in symptoms of Kitibha kushta

Table no 2:-Showing effect of Vasantika vamana karma in symptoms of Kitibha kushta

\begin{tabular}{|c|c|c|c|c|c|c|c|c|c|}
\hline \multirow{2}{*}{$\begin{array}{l}\text { Chief } \\
\text { complaints }\end{array}$} & \multirow{2}{*}{$\begin{array}{l}\text { No. } \\
\text { patients }\end{array}$} & \multicolumn{2}{|c|}{ Mean } & \multirow[t]{2}{*}{ S.D } & \multirow[t]{2}{*}{ S.E } & \multirow{2}{*}{ "t" } & \multirow{2}{*}{$\begin{array}{l}\text { "p" } \\
\text { value }\end{array}$} & \multirow[t]{2}{*}{ Remarks } & \multirow{2}{*}{$\begin{array}{l}\% \text { of } \\
\text { improvement }\end{array}$} \\
\hline & & BT & AT & & & & & & \\
\hline Kandu & 10 & 1.00 & 0.60 & 0.52 & 0.16 & 2.4495 & 0.0368 & $S$ & $40 \%$ \\
\hline $\begin{array}{l}\text { Shyava } \\
\text { varna }\end{array}$ & 10 & 1.00 & 0.90 & 0.32 & 0.10 & 1.000 & 0.3434 & N.S & $10 \%$ \\
\hline $\begin{array}{l}\text { Khara } \\
\text { sparsha }\end{array}$ & 10 & 1.00 & 0.60 & 0.52 & 0.16 & 2.4495 & 0.0368 & $\mathrm{~S}$ & $40 \%$ \\
\hline Daha & 4 & 0.40 & 0.00 & 0.00 & 0.00 & 2.4495 & 0.0368 & S & $100 \%$ \\
\hline
\end{tabular}

1. Significant results are seen in Kandu, Khara sparsha and Daha

2. Insignificant results are seen in Shyava varna

\section{Effect of Vasantika vamana in symptoms of Sthoulya}

Table no 3: Showing effect of Vasantika vamana karma in symptoms of Sthoulya

\begin{tabular}{|l|l|l|l|l|l|l|l|l|l|}
\hline $\begin{array}{l}\text { Chief } \\
\text { complaints }\end{array}$ & $\begin{array}{l}\text { No. of } \\
\text { patients }\end{array}$ & Mean & S.D & S.E & $\begin{array}{l}\text { "t" } \\
\text { value }\end{array}$ & $\begin{array}{l}\text { "p" } \\
\text { value }\end{array}$ & Remarks & $\begin{array}{l}\% \text { of } \\
\text { improvement }\end{array}$ \\
\cline { 6 - 11 } $\begin{array}{l}\text { Weight } \\
\text { reduction }\end{array}$ & 10 & 1.00 & 0.30 & 0.48 & 0.15 & 4.5826 & 0.0013 & H.S & $70 \%$ \\
\hline BMI & 10 & 1.00 & 0.30 & 0.48 & 0.15 & 4.5826 & 0.0013 & H.S & $70 \%$ \\
\hline
\end{tabular}

Highly significant results are seen in reduction of weight and BMI

Effect of Vasantika vamana symptoms of Tamaka swasa

Table no 3:-Showing effect of Vasantika vamana karma in symptoms of Tamaka swas

\begin{tabular}{|c|c|c|c|c|c|c|c|c|c|}
\hline \multirow{2}{*}{$\begin{array}{l}\text { Chief } \\
\text { complaints }\end{array}$} & \multirow{2}{*}{$\begin{array}{l}\text { No. of } \\
\text { patient }\end{array}$} & \multicolumn{2}{|l|}{ Mean } & \multirow[t]{2}{*}{ S.D } & \multirow[t]{2}{*}{ S.E } & \multirow{2}{*}{$\begin{array}{l}\text { "t" } \\
\text { value }\end{array}$} & \multirow{2}{*}{$\begin{array}{l}\text { "p" } \\
\text { value }\end{array}$} & \multirow[t]{2}{*}{ Remarks } & \multirow{2}{*}{$\begin{array}{l}\% \text { of } \\
\text { improvement }\end{array}$} \\
\hline & & BT & AT & & & & & & \\
\hline Swasa kruchrata & 10 & 1.00 & 0.50 & 0.53 & 0.17 & 3.000 & 0.0077 & $\mathrm{~S}$ & $50 \%$ \\
\hline Ghurghuraka & 10 & 1.00 & 0.50 & 0.53 & 0.17 & 3.000 & 0.0150 & $\mathrm{~S}$ & $50 \%$ \\
\hline Kasa & 10 & 1.00 & 0.70 & 0.48 & 0.15 & 1.9640 & 0.0811 & N.S & $30 \%$ \\
\hline
\end{tabular}

1. Significant results are seen in Swasa kruchrata and Ghurghuraka

2. Insignificant results are seen in Kasa

\section{Effect of Vasantika vamana in symptoms of Hypothyroidism}

Table no 5:-Showing effect of Vasantika vamana karma in symptoms of Hypothyroidism

\begin{tabular}{|l|l|l|l|l|l|l|l|l|l|l|}
\hline $\begin{array}{l}\text { Chief } \\
\text { complaints }\end{array}$ & $\begin{array}{l}\text { No. of } \\
\text { patient }\end{array}$ & Mean & BT & AT & & S.E & $\begin{array}{l}\text { "t" } \\
\text { value }\end{array}$ & $\begin{array}{l}\text { "p" } \\
\text { value }\end{array}$ & Remarks & $\begin{array}{l}\% \\
\text { improvement }\end{array}$ \\
\hline $\begin{array}{l}\text { Puffiness of } \\
\text { face }\end{array}$ & 4 & 0.40 & 0.00 & 0.00 & 0.00 & 2.4495 & 0.0368 & S & $100 \%$ \\
\hline $\begin{array}{l}\text { Dry \& course } \\
\text { skin }\end{array}$ & 7 & 0.70 & 0.00 & 0.48 & 0.00 & 4.5826 & 0.0013 & H.S & $100 \%$ \\
\hline Constipation & 10 & 1.00 & 0.20 & 0.42 & 0.13 & 6.000 & 0.0002 & H.S & $80 \%$ \\
\hline
\end{tabular}




\begin{tabular}{|l|l|l|l|l|l|l|l|l|l|}
\hline Lethargy & 6 & 0.60 & 0.20 & 0.42 & 0.13 & 2.4495 & 0.0368 & $\mathrm{~S}$ & $66.66 \%$ \\
\hline
\end{tabular}

1. Highly significant results are seen in relief from constipation and dry and course skin of patients.

2. Significant results are seen in puffiness and lethargy of the patients.

\section{Discussion:-}

\section{Kitibha kushta}

Kitibha kushta is a Kapha pradhana tridoshaja vyadhi. "Twachaha kurvanthi vaivarnya dushtam kushtamushanthi tat"(13) - That which causes vitiation and discoloration of skin is called Kushta. Along with Tridoshas, kleda plays an important role in the pathogenesis of Kitibha kushta. The accumulation of kleda results in Srotorodha leading to Vata vriddhi, because of the combined effect of Vata vriddhi and Srotavarodha, the Rasa dhatu does not enter in the Srotas. Twacha being dependent on Rasa dhatu, because of improper circulation of Rasadhatu, Shithilata of twacha takes place and give Shyava varna due to Vata vriddhi. At the same time due to Ushna guna of pitta, The Drava amsha of kleda will be expelled through Sweda. Due to loss of this Dravamsha the kleda that remains in Twacha will be transferred into Ghanibhuta kleda. This results in Parushata and Khara sparsha of twacha in Kitibha kushta ${ }^{(13)}$.

\section{Sthoulya ${ }^{(14)}$}

Sthoulya is a Kapha dosha pradhana and Mamsa and Meda dhatu pradhana vyadhi. Indulging more of Madhura snigdha ahara, Diwaswapna, lack of physical and mental activity produces derangement of Agni and there by produce the Amarasa which derange the metabolism of Meda and Mamsa dhatu. The accumulated Medo dhatu cause impairment in the Chala guna of Vata dosha causes increase of Agni, hence the consumed food is converted into Vikruta meda and Mamsa dhatu .

\section{Tamaka swasa ${ }^{(15)}$}

Tamaka swasa is defined as "visheshat durdine tamye swasa sa tamako matah" mean the attack of Swasa with Tama pravesha which occur especially during Durdina. It predominantly cause Vatakaphaja vyadhi, originating from the Amashaya and manifest through Pranavaha srotus. Vata gets obstructed by Kapha and travels into Pratiloma gati and causes Shwasa krichrata, Ghurghurakata and Kasa.

\section{Hypothyroidism}

The clinical presentation of Hypothyroidism show resemblance with different clinical condition described in Ayurvedic classics up to some extent. These include Kaphavrita udana vata ${ }^{(16)}$, Kaphavrita samana vata ${ }^{(17)}$. Hypothyroidism is a Kapha pradhana trodoshaja vyadi with Rasa and Medo dushti are predominant. Because of indulging more of Kapha kara ahara cause Dhatvagni mandya which play a major role in pathogenesis of Hypothyroidism. As it is one of the Margavaranajanaya vyadhi, hence Sroto shodhana, Agnideepana and Vatanulomana are the main principle of treatment.

\section{Mode of action Vasantika vamana in Kitibha kushta, Sthouly, Tamaka swasa and Hypothyroidism:}

Chaya of Kapha dosha is takes place in Shishira rutu because of taking more of Madura, Amla, Lavana rasa and Snigdha guna ahara in excess, as these are the Nidanas for vyadhi mentioned above. These increased Vikruta kapha dosha gets accumulated in Aamashaya in Vasanta rutu. Hence the Upasthita dosha in Aamashaya is expelled out through the Vamana karma in Vasanta rutu ${ }^{(4)}$.

\section{Chart No 02-}

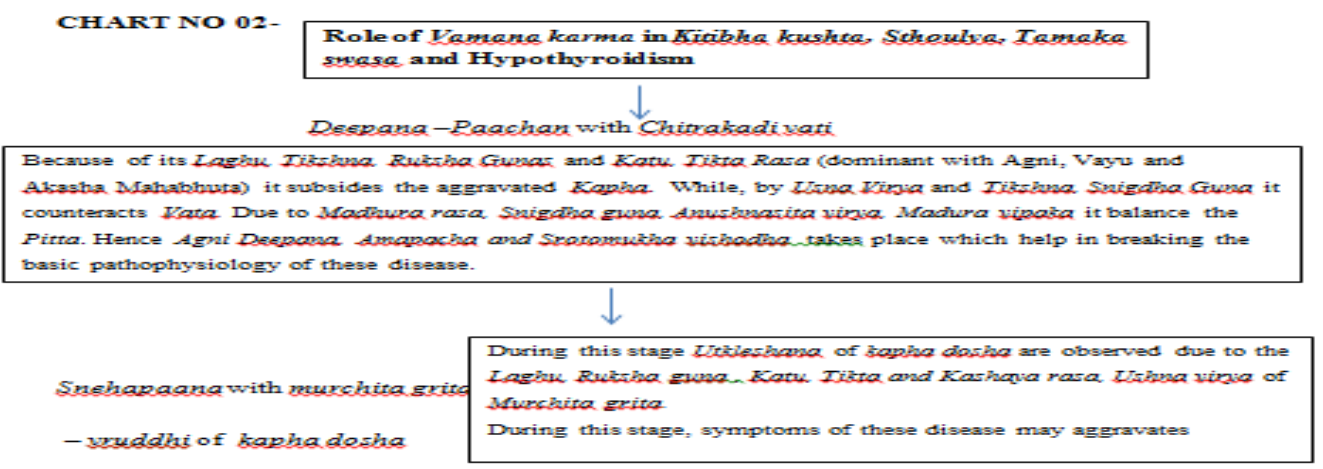




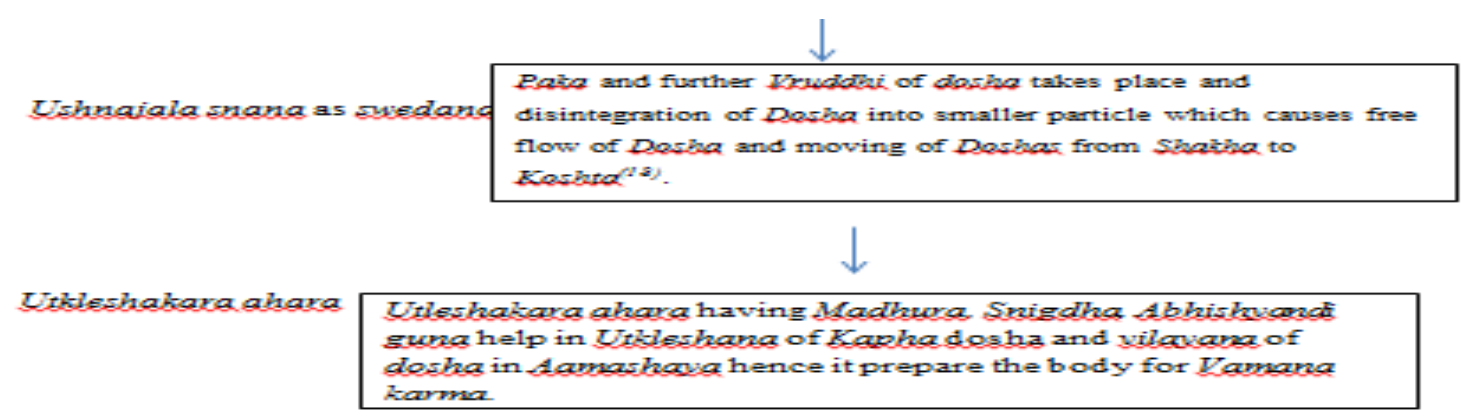

Utkleshakara ahara

Till this stage person attains the samyak avastha for vamana karma

\section{Vamana dravya -}

Madana phala pippali choorna added with Yashimadhu choorna, Vacha choorna, Saindhava lavana and Madu is administered.

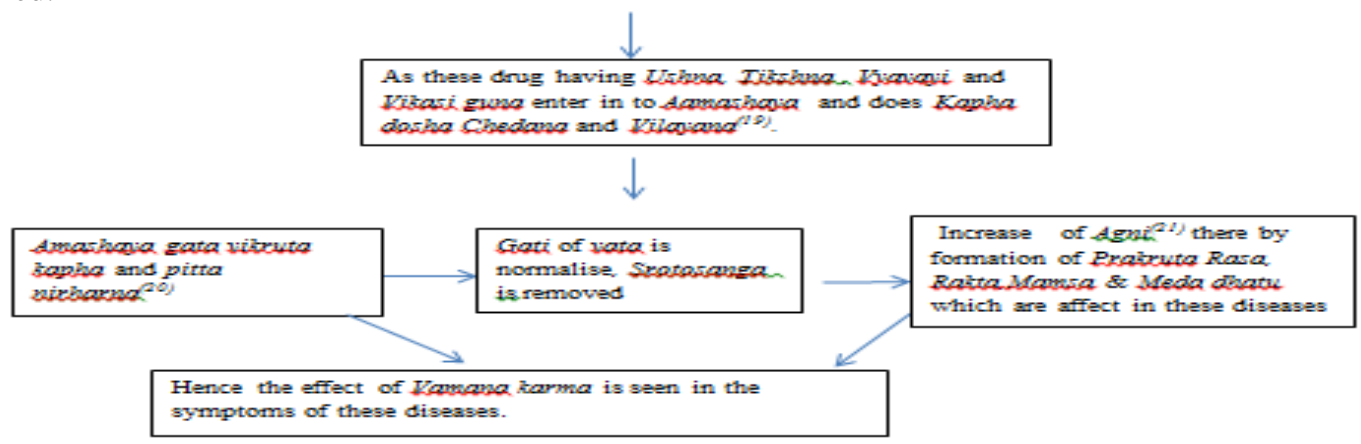

\section{Conclusion:-}

Vasantika vamana is a Rutu Shodhana process advised for both Swastha for maintaining the health and the diseased person to prevent and control the disease progress. Kitibha kushta, Sthoulya, Tamaka swasa and Hypothyroidism are Kapha pradhana and Bahudoshaavsthajanya vyadhi. Hence Nirharana of Kapha dosha in proper Rutu brings Indriya shuddhi, Sthirata of Rasadi dhatu and Agni Deepana as deranged Agni is the pathology in these diseases.

Along with the Rutu shodhan, following proper Dinacharya and Rutucharya is important to maintain the healthy state of body as well as mind.

Kitibha kushta, Sthoulya, Tamaka swasa and Hypothyroidism are Dirghakalina vyadhi hence Nidana parivarjana help to arrest the progression of disease.

As these diseases are Gambhira and Chirakalanubandhi, Stoka Stoka Dosha nirharana are in particular rutu based on the roga and rogi bala are helpful to maintain the health and disease progression.

\section{Bibliography:-}

1. Vagbhata, Sutra stana, Ashtanga Hrudaya with the commentaries of Sarvanga sundara of Arunadatta and Ayurveda rasayana of Hemadri, (Ed) Pt Hari Sadashiva shastri paradakara Bhishagacharya, Chaukamba surbharati prakashana, Varanasi reprint 2010, chapter-14, verse-5, p-22

2. Vagbhata, Sutra stana, Ashtanga Hrudaya with the commentaries of Sarvanga sundara of Arunadatta and Ayurveda rasayana of Hemadri, (Ed) Pt Hari Sadashiva shastri paradakara Bhishagacharya, Chaukamba surbharati prakashana, Varanasi reprint 2010, chapter-18, verse-1, p-260.

3. Vagbhata, Sutra stana, Ashtanga Hrudaya with the commentaries of Sarvanga sundara of Arunadatta and Ayurveda rasayana of Hemadri, (Ed) Pt Hari Sadashiva shastri paradakara Bhishagacharya, Chaukamba surbharati prakashana, Varanasi reprint 2010, chapter-3, verse-17, p-42. 
4. Vagbhata, Sutra stana, Ashtanga Hrudaya with the commentaries of Sarvanga sundara of Arunadatta and Ayurveda rasayana of Hemadri, (Ed) Pt Hari Sadashiva shastri paradakara Bhishagacharya, Chaukamba surbharati prakashana, Varanasi reprint 2010, chapter-3, verse-18, p-43.

5. Vagbhata, Sutra stana, Ashtanga Hrudaya with the commentaries of Sarvanga sundara of Arunadatta and Ayurveda rasayana of Hemadri, (Ed) Pt Hari Sadashiva shastri paradakara Bhishagacharya, Chaukamba surbharati prakashana, Varanasi reprint 2010, chapter-3, verse-18, p-43.

6. Agnivesha, Chikitsa stana, Charaka samhita, Ayurvedadipika commentary by Sri Chakrapanidatta, (Ed) Vaidya Yadavji Trikamji Acharya, Chaukamba surbharati prakahana, Varanasi reprint 2014, chapter-7, verse-4-8, p450 .

7. Agnivesha, Sutra stana, Charaka samhita, Ayurvedadipika commentary by Sri Chakrapanidatta, (Ed) Vaidya Yadavji Trikamji Acharya, Chaukamba surbharati prakahana, Varanasi reprint 2014, chapter-23, verse-3-5, p123.

8. Agnivesha, Chikitsa stana, Charaka samhita, Ayurvedadipika commentary by Sri Chakrapanidatta, (Ed) Vaidya Yadavji Trikamji Acharya, Chaukamba surbharati prakahana, Varanasi reprint 2014, chapter-17, verse-14-16, p-533.

9. Agnivesha, Chikitsa stana, Charaka samhita, Ayurvedadipika commentary by Sri Chakrapanidatta, (Ed) Vaidya Yadavji Trikamji Acharya, Chaukamba surbharati prakahana, Varanasi reprint 2014, chapter-15, verse-16-17, p-521.

10. Agnivesha, Kalpa stana, Charaka samhita, Ayurvedadipika commentary by Sri Chakrapanidatta, (Ed) Vaidya Yadavji Trikamji Acharya, Chaukamba surbharati prakahana, Varanasi reprint 2014, chapter-1, verse-13, p-654.

11. Vagbhata, Sutra stana, Ashtanga Hrudaya with the commentaries of Sarvanga sundara of Arunadatta and Ayurveda rasayana of Hemadri, (Ed) Pt Hari Sadashiva shastri paradakara Bhishagacharya, Chaukamba surbharati prakashana, Varanasi reprint 2010, chapter-18, verse-27, p-265.

12. Agnivesha, Siddhi stana, Charaka samhita, Ayurvedadipika commentary by Sri Chakrapanidatta, (Ed) Vaidya Yadavji Trikamji Acharya, Chaukamba surbharati prakahana, Varanasi reprint 2014, chapter-1, verse-13-14, p679.

13. Agnivesha, Siddhi stana, Charaka samhita, Ayurvedadipika commentary by Sri Chakrapanidatta, (Ed) Vaidya Yadavji Trikamji Acharya, Chaukamba surbharati prakahana, Varanasi reprint 2014, chapter-1, verse-15, p-670.

14. Vagbhata, Nidana stana, Ashtanga Hrudaya with the commentaries of Sarvanga sundara of Arunadatta and Ayurveda rasayana of Hemadri, (Ed) Pt Hari Sadashiva shastri paradakara Bhishagacharya, Chaukamba surbharati prakashana, Varanasi reprint 2010, chapter-14, verse-3, p-524.

15. Agnivesha, Sutra stana, Charaka samhita, Ayurvedadipika commentary by Sri Chakrapanidatta, (Ed) Vaidya Yadavji Trikamji Acharya, Chaukamba surbharati prakahana, Varanasi reprint 2014, chapter-21, verse-5-6, p117.

16. Agnivesha, Chikitsa stana, Charaka samhita, Ayurvedadipika commentary by Sri Chakrapanidatta, (Ed) Vaidya Yadavji Trikamji Acharya, Chaukamba surbharati prakahana, Varanasi reprint 2014, chapter-17, verse-55-62, p-535.

17. Agnivesha, Chikitsa stana, Charaka samhita, Ayurvedadipika commentary by Sri Chakrapanidatta, (Ed) Vaidya Yadavji Trikamji Acharya, Chaukamba surbharati prakahana, Varanasi reprint 2014, chapter-29, verse-224, p626.

18. Agnivesha, Chikitsa stana, Charaka samhita, Ayurvedadipika commentary by Sri Chakrapanidatta, (Ed) Vaidya Yadavji Trikamji Acharya, Chaukamba surbharati prakahana, Varanasi reprint 2014, chapter-29, verse-226, p626.

19. Agnivesha, Sutra stana, Charaka samhita, Ayurvedadipika commentary by Sri Chakrapanidatta, (Ed) Vaidya Yadavji Trikamji Acharya, Chaukamba surbharati prakahana, Varanasi reprint 2014, chapter-28, verse-34, p180 .

20. Agnivesha, Kalpa stana, Charaka samhita, Ayurvedadipika commentary by Sri Chakrapanidatta, (Ed) Vaidya Yadavji Trikamji Acharya, Chaukamba surbharati prakahana, Varanasi reprint 2014, chapter-1, verse-5, p-651.

21. Agnivesha, Siddhi stana, Charaka samhita, Ayurvedadipika commentary by Sri Chakrapanidatta, (Ed) Vaidya Yadavji Trikamji Acharya, Chaukamba surbharati prakahana, Varanasi reprint 2014, chapter-6, verse-22, p-705. 